\title{
CROSS NEUTRALIZATION OF SOME KINDS OF SCORPION VENOMS FROM AFRICA AND SOUTH EAST USING VACSERA POLYVALENT SCORPION ANTISERA
}

\section{By}

\author{
ABIR A. ELFIKY ${ }^{1}$, HODA R. ATTIA ${ }^{2}$ and MOAAZ R. ABD ELAZIZ ${ }^{2}$ \\ VACSERA, Dokki, Giza ${ }^{1}$ and Faculty of Biotechnology, October University for \\ Modern Science and Arts, October City ${ }^{2}$, Giza, Egypt \\ ( ${ }^{\star}$ Correspondence: elfikyabir@gmail.com) \\ Abstract
}

Preparation of scorpion antivenin includes administration of the venom to a suitable animal mostly horses- and after an appropriate period collecting the specific antibodies from the serum of the inoculated animal. During such procedure the recipient animal may suffer different types of ill-health signs including, generalized asthenia, pallor, skin rashes, muscular pain, hemorrhages, cardiovascular, respiratory problems, nervous signs as paresis and paralysis, break down of tissues, and finally collapse and death, The severity and duration of the observed clinical signs depend on the nature, amount and site of the injected venoms Genus scorpion is widespread throughout Western and Central Asia. It is a genus in constant revision and recognizes a number of subspecies. An extensive study was conducted of neutralization of lethality of four species of scorpions from Egypt including Leurus quinquestriatus, Androctonus crassicauda, Androctonus amorexi, and Androctonus australis and three species of scorpions from Yemen including Leurus quinquestriatus, Bothus spp. and Androctonus australis by VACSERA equine scorpion antisera. The results revealed that $\mathrm{LD}_{50}$ venoms was 6.9 , $8.3,12.5, \& 6.94 \mathrm{LD}_{50} /$ mouse consequently for Egyptian venoms, while $\mathrm{LD}_{50}$ of the previous mentioned venoms from Yamen was $6.4 \pm 6,20.7 \& 7.0 \mathrm{LD}_{50} /$ mouse consequently. Polyvalent scorpion venom antisera by injection of horses by L. quinquestriatus, A. crassicauda proved effective in neutralizing specifically Egyptian L. quinquistriatus, and A. crassicauda, by $70, \&$ 35 LD50/mouse, and paraspecifically other scorpion species including Egyptian A. amorexi, and $A$. australis by 45 , and $60 \mathrm{LD}_{50} /$ mouse. Polyvalent scorpion venom antisera neutralized Yameni species as follow $70 \mathrm{LD}_{50} /$ mouse for Leurus, $60 \mathrm{LD}_{50}$ /mouse for A. australis, and 20 LD50/mouse for Bothus spp.

Key words: African scorpion venoms, VACSERA polyvalent scorpion antisera

\section{Introduction}

Scorpion venom, which has lethal and paralytic effects, is a secretion composed of water, salts and simple, low molecular-weight proteins (Ozkan et al, 2006a). Scorpion envenomation remains a major health problem in many tropical and subtropical countries (Ozkan et al, 2006b,c). Preparation of scorpion antivenom includes administration of the Leurus quinquistriatus, and Androctonus crassicauda venom to the suitable animal mostly horses- and after an appropriate period collecting the specific antibodies from the serum of the inoculated animal.

During such procedure the recipient animal may suffer different types of ill-health signs including, the generalized asthenia, pallor, skin rashes, muscular pain, hemorrhag- es, cardiovascular, respiratory problems, and nervous signs as paresis and paralysis, break down of tissues, and finally collapse and death (Ghalim et al, 2000). The severity and duration of the observed clinical signs depend on the nature, amount and site of the injected venoms. Genus scorpion is widespread throughout Africa, Western and Central Asia. It is a genus in constant revision and recognizes a number of subspecies. Scorpion hemocyanins induce triple enzymatic function pseudo-catalasic, peroxydasic and superoxide-dismutasic. Buthidae venom hemo-cyanins was resistant to several environmental stressors such as (dehydrationmicrobial infections- ionizing radiations). Oukkache et al. (2013) reported a high hemocyanin contamination in scorpion venom 
obtained by the manual stimulation method. Indeed, the corresponding antivenom produced from the venom obtained manually presents a high percentage of specific antibodies that neutralize the hymolymph molecules and few specific antibodies that neutralize scorpion toxins.

The venoms obtained by electrical stimulation may contribute to the production of better antivenom with the higher neutralization potency. As to its advantages in relation to the manual method, electrical stimulation not only enables the collection of nearly $100 \%$ of the venom, but also yields more venom than manual stimulation with a higher content of toxins.

\section{Material and Methods:}

Venoms: Pure Leurius quinquistriatus (Egypt and Yemen), Androctonus crassicauda (Egypt), Androctonus amorexi (Egypt), Androctonus australis (Egypt and Yemen), and Bothus species (Egypt).

Antivenom: polyvalent scorpion venom antisera from VACSERA, Egypt is a divalent antiserum which prepared by injection of horses by Leurus quinquistriatus, Androctonus crassicauda venoms and after an appropriate period collecting the specific antibodies from the serum of the inoculated animal. Experimental antiserum used in the study consisted of equivolumetric pools of the sera of the horses in each group.

Animals: For lethal potency 18-20gm and 16-18gm laboratory bred Albino Swiss male mice (VACSERA), ) were used for neutralization. All mice experimentation were carried out in accordance with the Guide for the Care and Use of Laboratory Animals (U.S. National Research Council, 2002).

Protein concentration measuring (Stoscheck, 1990): Protein was determined by absorbance measurment at $280, \& 260 \mathrm{~nm}$ for each venom type as final concentration of $1 \mathrm{mg} / \mathrm{ml}$.

Gel electrophoresis of venom (Laemmli, 1970): Electrophoresis analysis of venoms was performed on $15 \%$ polyacrylamide gel in the presence of SDS under reducing con- ditions. All samples were disolved in a sample buffer (50mM Tris-Hcl, pH 6.8, 0.1 M DDT, $10 \%$ glycerol, $2 \%$ SDS, and bromophenol blue). A constant electrec current of $70 \mathrm{~mA}$ was applied for two hours. After migration, the gel was stained with Coomassie Brillient Blue R 250.

Determination of $\mathrm{LD}_{50}$ : Different doses of each venom species were injected intravenously in mice (5mice/dose) according to conventional techniques (WHO, 2010a). The number of deaths $48 \mathrm{hrs}$ after injection was recorded and the lethal potency calculated as $\mathrm{LD}_{50}$, the dose of venom in $\mathrm{ug} / \mathrm{mouse}$ that causes a statistical mortality of $50 \%$. The plot of mortality versus venom dose was analyzed by nonlinear regression.

Neutralization of lethality: (WHO, 2010) Different doses of antivenom were incubated with five median lethal doses (LD50) of each venom species for $30 \mathrm{~min}$ at $37^{\circ} \mathrm{C}$. After incubation, samples were injected intravenously (i.v.) in mice (n $1 / 45 /$ dose level). The number of deaths $48 \mathrm{~h}$ after injection was recorded and the median Effective Doses (ED50) were calculated as the antivenom dose in microliters that protected $50 \%$ of the mice. Anti-venom potency was calculated using the formula Potency $1 / 4\left[(n-1) / E_{50}\right]$ ? $\mathrm{LD}_{50}$, where $\mathrm{n}-1$ represents the number of lethal doses of the challenge minus one. LD50 subtracted from the total challenge dose $(n)=$ the theoretical dose responsible for the death of half the mice, i.e. the calculation based on the total challenge minus one represents the actual quantity of venom that would be otherwise responsible for $100 \%$ mortality and was therefore neutralized by the antivenom. As the $\mathrm{ED}_{50}=\mathrm{ex}$ pressed in $\mathrm{LD}_{50} /$ mouse, the final result is LD50/mouse), indicating the $\mathrm{LD}_{50}$ of venom doses neutralized by $1 \mathrm{ml}$ polyvalent scorpion antivenom.

Ethical Approval: All the procedures involving animals were in accordance with the ethical principals in animal research adopted (WHO, 2010).

Statistical analysis: Data were processed 
statistically (Snedecor and Cochran, 1982), where minimum, maximum, mean value, standard deviation, standard error, and range

\section{Results}

Geographic distribution and measurement of protein concentration (Tabs. $1 \& 2$ )

Table1: Geographic regions of scorpions used.

\begin{tabular}{|l|l|l|}
\hline Scorpion & Description & Representation and region of scorpion (habitat) \\
\hline $\begin{array}{l}\text { Leurus quin- } \\
\text { quistriatus, }\end{array}$ & $\begin{array}{l}\text { Leiurus quinquestriatus yellow, and } \\
30-77 \mathrm{~mm} \text { (1.2-3.0 inch) long, with an } \\
\text { average of 58 mm (2.3 in). (WRBU } \\
\text { Scorpion Identification, 2011) } \\
\text { - }\end{array}$ & $\begin{array}{l}\text { Leiurus quinquestriatus in desert and scrubland habi- } \\
\text { tats from North Africa to Middle East, covering a } \\
\text { wide sweep of territory in Sahara, Arabian Desert, and } \\
\text { Central Asia, from Algeria and Mali in west through } \\
\text { Egypt, Ethiopia, Asia Minor and Arabian Peninsula, } \\
\text { eastwards to Kazakhstan and western India in north- } \\
\text { east \& southeast. (WRBU Scorpion Identification, } \\
\text { 2011) }\end{array}$ \\
\hline $\begin{array}{l}\text { Androctonus } \\
\text { crassicauda }\end{array}$ & $\begin{array}{l}\text { A. crassicauda a desert species, an } \\
\text { Old World scorpion. Adults can vary } \\
\text { in color from a light brown to reddish } \\
\text { to blackish-brown, to black, grow to } \\
\text { over 10cm (3.9 inch) in length. (Ait } \text { et } \\
\text { al, 2018). }\end{array}$ & $\begin{array}{l}\text { In Palaearctic region.as Saudi Arabia, Iran, Turkey, } \\
\text { and in north African nations (Ait } \text { et al, 2018). }\end{array}$ \\
\hline $\begin{array}{l}\text { Androctonus } \\
\text { Amorexi }\end{array}$ & $\begin{array}{l}\text { Very similar in size, appearance, \& } \\
\text { physical characters to A. australis \& } \\
\text { A. crassicauda } \text { (Living Hazards Data- } \\
\text { base, 2000) }\end{array}$ & $\begin{array}{l}\text { Fairly wide-spread in northern Africa \& Middle East, } \\
\text { also in Iraq, Syria, \& Libya. For general description of } \\
\text { typical habitat for a closely-related species (Living } \\
\text { Hazards Database, 2000) }\end{array}$ \\
\hline $\begin{array}{l}\text { Androctonus } \\
\text { Australis }\end{array}$ & $\begin{array}{l}\text { Large in size, pale -yellow with dark } \\
\text { spots (Gantenbein and Largiadèr, } \\
\text { 2003). }\end{array}$ & $\begin{array}{l}\text { Wide spread in north Africa, Somali, India, Pakistan, } \\
\text { and Middle East countries in very hot deserts ( Gan- } \\
\text { tenbein and Largiadèr, 2003). }\end{array}$ \\
\hline $\begin{array}{l}\text { Bethus speci- } \\
\text { es }\end{array}$ & $\begin{array}{l}\text { 7.5cm long. Body all dark-brown, legs } \\
\text { lighter, brown to yellowish-brown; } \\
\text { post-abdomen relatively thick \& wide } \\
\text { (Steve, 2011). }\end{array}$ & $\begin{array}{l}\text { Semi-arid, arid, or desert areas with limited vegeta- } \\
\text { tion, sometimes in margins of cultivated land \& oases; } \\
\text { from near sea level up to at least 300 m elevation, } \\
\text { southern Europe, on several Mediterranean islands, } \\
\text { Northern Africa \& Middle East (Steve, 2011). }\end{array}$ \\
\hline
\end{tabular}

were presented. Comparison between groups

for significance was done using t. test.

Table 2: Total protein of all venoms used

\begin{tabular}{|l|c|}
\multicolumn{2}{|c|}{ Table 2: Total protein of all venoms used } \\
\hline \multicolumn{1}{|c|}{ venom } & $\mathrm{TP}(\mathrm{mg} / \mathrm{ml})$ \\
\hline Leurus quinquestriatus Egypt & $1.523 \pm 0.47$ \\
\hline Leurus quinquestriatus Yemen & $0.91 \pm 0.4$ \\
\hline Androctonus crassicauda Egypt & $0.394 \pm 0.03$ \\
\hline Androctonus amorexi Egypt & $1.259 \pm 0.12$ \\
\hline Androctonus australis Egypt & $1.414 \pm 0.34$ \\
\hline Androctonus australis Yamen & $1.413 \pm 0.35$ \\
\hline Bothus species Egypt. & $1.3 \pm 0.12$ \\
\hline
\end{tabular}

Gel electrophoresis of scorpion venom: Difference between scorpions venom found differences in presence of gel bands in every species. In Leurus venom showed clear bands at $3.5,6,15,18, \& 24 \mathrm{Kda}$ and faint bands at $31,42,57,72,83 \& 240 \mathrm{Kda}$. In Australis venom showed clear bands at 3.5, 6, 42 , \& $125 \mathrm{kda}$, and faint bands at 15, 24, 31, 57, 72, \& $165 \mathrm{kda}$. Androctonus amorexi venom showed bands appear at 3.5, 6, 15,
24, 42, and $125 \mathrm{Kda}$, and faint bands at 31 , 72 , \& 83 kda. Bothus venom showed clear bands at 3.5, 42, 83, 165, \& $240 \mathrm{kda}$, and faint bands at 6, \& $125 \mathrm{kda}$ (Fig. 1).

Median Lethal dose of venoms: The most potent was L. quinquistriatus venom was 6.9 ug/mice, while Androctonus crassicauda was (8.3ug/mice), Androctonus amorexi was (12.5ug/mice) Androctonus australis was (6.94ug/mice) as in (Tab. 3). 
Table 3: median lethal dose of venom (LD50 in ug/mouse, 18-20 g mice) of all venoms used

\begin{tabular}{|l|l|l|}
\hline Venom & Source & LD50 (95\% c.i.) \\
\hline Leurus quinquestriatus & VACSERA Serpentarium & $6.9 \pm 0.1$ \\
\hline Leurus quinquestriatus & Elbalsam Company Yamen & $6.4 \pm 0.6$ \\
\hline Androctonus crassicauda & VACSERA Serpentarium & $8.3 \pm 0.9$ \\
\hline Androctonus amorexi & VACSERA Serpentarium & $12.5 \pm 0.5$ \\
\hline Androctonus australis & Elbalsam Company, Yemen & $6.94 \pm 0.7$ \\
\hline Androctonus australis & Yemen Yamen & $7.0 \pm 0.5$ \\
\hline Bothus occitanus & $20.7 \pm 0.4$ \\
\hline $\begin{array}{l}\text { (-) indicates a confidence interval of <0.01 calculated with just one intermediate survival value at } \\
\text { very close doses. }\end{array}$
\end{tabular}

Range of specific neutralization potency was from $35 \mathrm{LD}_{50}$ Androctonus crassicauda venom, to $70 \mathrm{LD}_{50}$ Leurus quinquestriatus venom from Egypt and Yamen, whereas paraspecific neutralization ranges $45 \mathrm{LD}_{50}$

Table 4: Neutralization of lethality by polyvalent scorpion antivenom

\begin{tabular}{|c|c|}
\hline Venom & *LD50 doses neutralized by 1ml polyvalent scorpion antivenom \\
\hline Leurus quinquestriatus Egypt & $70 \pm 4.0$ \\
\hline Leurus quinquestriatus Yemen & $70 \pm 6.6$ \\
\hline Androctonus crassicauda & $35 \pm 3.6$ \\
\hline Androctonus amorexi & $45 \pm 4.2$ \\
\hline Androctonus australis Egypt & $60 \pm 6.1$ \\
\hline Androctonus australis Yemen & $60 \pm 6.3$ \\
\hline Bothus species & $20 \pm 2.6$ \\
\hline \multicolumn{2}{|c|}{ (*units = LD50/mouse) } \\
\hline
\end{tabular}

\section{Discussion}

Scorpion bites are a common problem in human and veterinary medicine. Scorpion venom contains a short sequence of neurotoxin polypeptides consisting of simple, low-molecular weight proteins that have lethal and paralytic effects. Venom toxicity varies according to several factors such as genus, species, age, physiology, feeding state and region of the scorpion. Then, major difficulties are related to standardizing venom quality (WHO, 2010b). To develop an antivenom that neutralizes the toxic effects of venoms as much as possible, we must have a high quality of venom with a high toxic activity $\left(\mathrm{LD}_{50}\right)$ containing a large amount of toxins. Scorpion antivenom immunoglobulins are the only specific treatment against envenomation from stings. That can prevent or reverse most effects of stings, and play crucial roles in minimizing mortality and morbidity as toxicity widely differs among species. There was an urgent need to ensure the availability of safe, effective and affordable antivenoms, particularly
Androctonus amorexi venom, $60 \mathrm{LD}_{50} A n$ droctonus australis venom from Egypt and Yemen, and $20 \mathrm{LD}_{50}$ for Bothus species venom (Tab. 4).

for developing countries, and to improve regulatory control over the manufacture, import, and sale of antivenoms (WHO, 2010a). Concerning gel electopheresis pattern we found that both Leurus venom from Egypt and Yemen gave the same bands, also $A n$ droctonus australis venom from Egypt and Yamen showed same bands. There were difference between other species of scorpions due to differences in components of their proteins and enzymes detected. These results agreed with Ismail et al. (1993) and Fet et al. (2000) as there are more than 1500 different species of scorpions worldwide of which 50 species proteins or peptides were characterized. Concerning venom toxicity, Leiurus venom from Egypt was nearly of the same toxicity as that of Yemen (6.9 for Egypt and 6.4 for Ymen). Also Androctonus Australis venom was 6.9 (Egypt) and 7.0 (Yemen). This result represented almost the same toxicity of the same species, and more or less agreed with Saganuwan (2018) who found that LD50 of A. Australis venom was $0.25 \mathrm{mg} / \mathrm{kg}$. As to toxicity of $A$. crassicauda 
venom was 8.3 (Egypt), which more or less agreed with Saganuwan (2018) who found $\mathrm{LD}_{50}$ of A. crassicauda venom was $35 \mathrm{ug} / \mathrm{kg}$. In the present study, toxicity of $A$. amorexi was 12.5, which agreed with Ozkan et al. (2007). LD $_{50}$ of scorpion venom varied even if the venom was extracted by using a single method. Ismail et al. (1994) found that of $A$. crassicauda venom LD50was $0.64 \mathrm{mg} / \mathrm{kg}$, (12.8ug/mouse), but Latoxan Laboratory reported the $\mathrm{LD}_{50}$ of $0.87 \mathrm{mg} / \mathrm{kg}$ (17ug/ mouse) for the same venom by the same method. Toxicity of Bothus venom was $20 \mathrm{ug} /$ mouse, which was more or less similar to Oukkache et al. (2014) who found it $15.2 \mathrm{ug} / \mathrm{mouse}$, but disagreed with Ait et al. (2018) who found $0.52 \mathrm{mg} / \mathrm{kg}$ due to geographical variations. The VACSERA polyvalent scorpion antisera were specifically neutralized by venom Leurus quinquestriatus from Egypt and Yemen by $70 \mathrm{LD}_{50}$ for both and also neutralize Egyptian Androctonus crassicauda by 35 $\mathrm{LD}_{50}$. Ad hoc, it was neutralized par specifically by Egyptian Androctonus amorexi by $45 \mathrm{LD}_{50}$ and $A$. australis from both Egypt and Yemen by $60 \mathrm{LD}_{50}$.

Bothus species venom was neutralized by VACSERA scorpion antivenom by $20 \mathrm{LD}_{50}$. Theses results agreed with Mohamed et al. (1974) who found weak neutralization by the Egyptian serum (Agouza Laboratories) of Leiurus quinquestriatus against the two Libyan scorpion venoms Androctonus aeneas and Buthus occitanes as $1 \mathrm{ml}$ neutralized 6\& $14 \mathrm{LD}_{50}$, respectively (Garrigues et al, 2005). This reflected the antigenic difference between the specific venoms used in immunization (Michael, 2007).

\section{Conclusion}

The neutralization of four species of scorpions from Egypt and three from Yemen by VACSERA equine scorpion antisera prepared by injection of horses by Leiurus quinquestriatus, Androctonus crassicauda was highly effective in neutralizing specifically Egyptian Leurus quinquestriatus, and Androctonus crassicauda, by $70 \& 35 \mathrm{LD}_{50} /$ mouse, and par-specifically other scorpions species including Egyptian $A$. amorexi, and A. australis by $45, \& 60 \mathrm{LD}_{50} /$ mouse. On the other hand, polyvalent scorpion venom antisera from vacsera neutralize Yemen species were $70 \mathrm{LD}_{50} /$ mouse for Leurus $60 \mathrm{LD}_{50} /$ mouse for A. australis, \& $20 \mathrm{LD}_{50} /$ mouse for Bothus spp.

\section{Recommendations}

More scorpion venoms from other countries could be tested for verification of their neutralization effect to wide range the use of VACSERA scorpion anti-venom for different countries and decrease incidence of toxicity due to scorpion envenomation

\section{Acknowledgments}

The authors are grateful to Dr Heba Wally, Chairman of VACSERA, and VASCERA Authorities. Thanks are also due to the Head Authorities of Faculty of Biotechnology, MSA University.

\section{References}

Ait MM, El Hidan, MA, Marhoume, F, Bouimeja, B, Oufquir, S, et al, 2018: Buthus lienhardi venom and pathophysiological effects at the histological, hematological, biochemical and motor skills levels, Toxicon 10.1016/j. toxicon. 2018.03.001.

Fet, V, Sissom, W, Lowe, GJ, Braunwalder, M, 2000: Catalog of the Scorpions of the World (1758-1998). The New York Entomology Society, New York, USA

Gantenbein, B, Largiadèr, CR, 2003: The phylogeographic importance of the Strait of Gibraltar as a gene flow barrier in terrestrial arthropods: A case study with the scorpion Buthus occitanus as model organism. Mol. Phylogen. Evol. 28, 1:119-30.

Ghalim, N, Elhafny, B, Sebti, F, Heikel, J, Lazar, N, et al, 2000: Scorpion envenomation and serotherapy in Morocco. Am. J. Trop. Med. Hyg. 62, 2:227-83.

Ismail, M, Abd-Elsalam MA, al-Ahaidib MS, 1994: Androctonus crassicauda (Olivier), a dangerous and unduly neglected scorpion. I- Pharmacological and clinical studies. Toxicon 32, 12:1599-618.

Laemmlim U.K, 1970: cleavage of structural proteins during the assembly of the head of bacteriophage T4. Nature 227, 5259:680-5.

Living Hazards Database, 2000: http://www. acq.osd.mil/eie/afpmb/docs/lhd/venomous_ani- 
mals_byspecies.pdf)

Oukkache, N, Chgoury, F, Lalaoui, M, Alagón, AC, Ghalim, N, 2013: Comparison between two methods of scorpion venom milking in Morocco. J. Venom. Anim. Toxins including Trop. Dis, 19:5 http://www.jvat.org/content/19/ $1 / 5$

Oukkache, N, El Jaoudi, R, Ghalim, N, Chgoury, F, Balkiss Bouhaouala, B, et al, 2014: Evaluation of the lethal potency of scorpion and snake venoms and comparison between intraperitoneal and intravenous injection routes. Toxins (Basel). 6, 6:1873-81.

Ozkan, O, Kar, S, Güven, E, Ergun, G, 2007: Comparison of proteins, lethality and immunogenic compounds of Androctonus crassicauda (Olivier, 1807) (Scorpiones: Buthidae) venom obtained by different methods. J. Venom. Anim. Toxins including Trop. Dis. 13, 4:844-56.

Ozkan, O, Adiguzel, S, Ates, C, Bozyigit, I, Filazi, A, 2006a: Optimization of antiscorpion venom production. J. Venom. Anim.Toxins Incl. Trop. Dis. 12, 390-9.

Ozkan, O, Adiguzel, S, Yakistiran, S, Cesar etli, Y, Orman, M, et al, 2006b: Scorpionism in the Saniliurfa region in Turkey. Acta Parasitol.
Turcica 30:239-45.

Ozkan, O, Adiguzel, S, Yakistiran, S, Filazi, A, 2006c: Study of the relationship between $A n$ droctonus crassicauda (Oliver, 1807; Scorpiones, Buthidae) venom toxicity and telson size, weight and storing condition. J. Venom. Anim. Toxins Includ. Trop. Dis. 12, 297-309.

Stoscheck, CM, 1990: Quantitation of proteins, Meth. Enzymol. 182:50-69.

Steve, B, 2011: Venom: Poisonous Animals in the Natural World. New Holland Publishers: ISBN 978-1-84773-870-7

Saganuwan, AS, 2018: Determination of median effective dose (ED) of scorpion antivenom against scorpion envenomation using a newly developed formula. Anim. Mod. Exp. Med. 1, 3: 228-34.

WHO, 2010a: WHO Guidelines for the production control and regulation of snake antivenom immunoglobulins. Geneva, Switzerland.

WHO, 2010b: WHO Guidelines for the Production, Control and Regulation of Scorpion Antivenom Immunoglobulins.who.int/blood products /scorpion antivenoms/database.

WRBU Scorpion Identification, 2011: Wrbu. si.edu. Retrieved 2011-12-05.

\section{Explanation figures}

Fig. 1: Gel electropheresis of scorpion venoms Leu1 Egypt, Leu 2 Yemen---Aust1 Egypt, Austr 2 Yemen, Bothus, Amorexi Fig. 2: Total proteins of venoms

Fig. 3: Median lethal dose of venom

Fig. 4: Neutralization of lethality by polyvalent scorpion antivenom produced by VACSERA, Egypt.

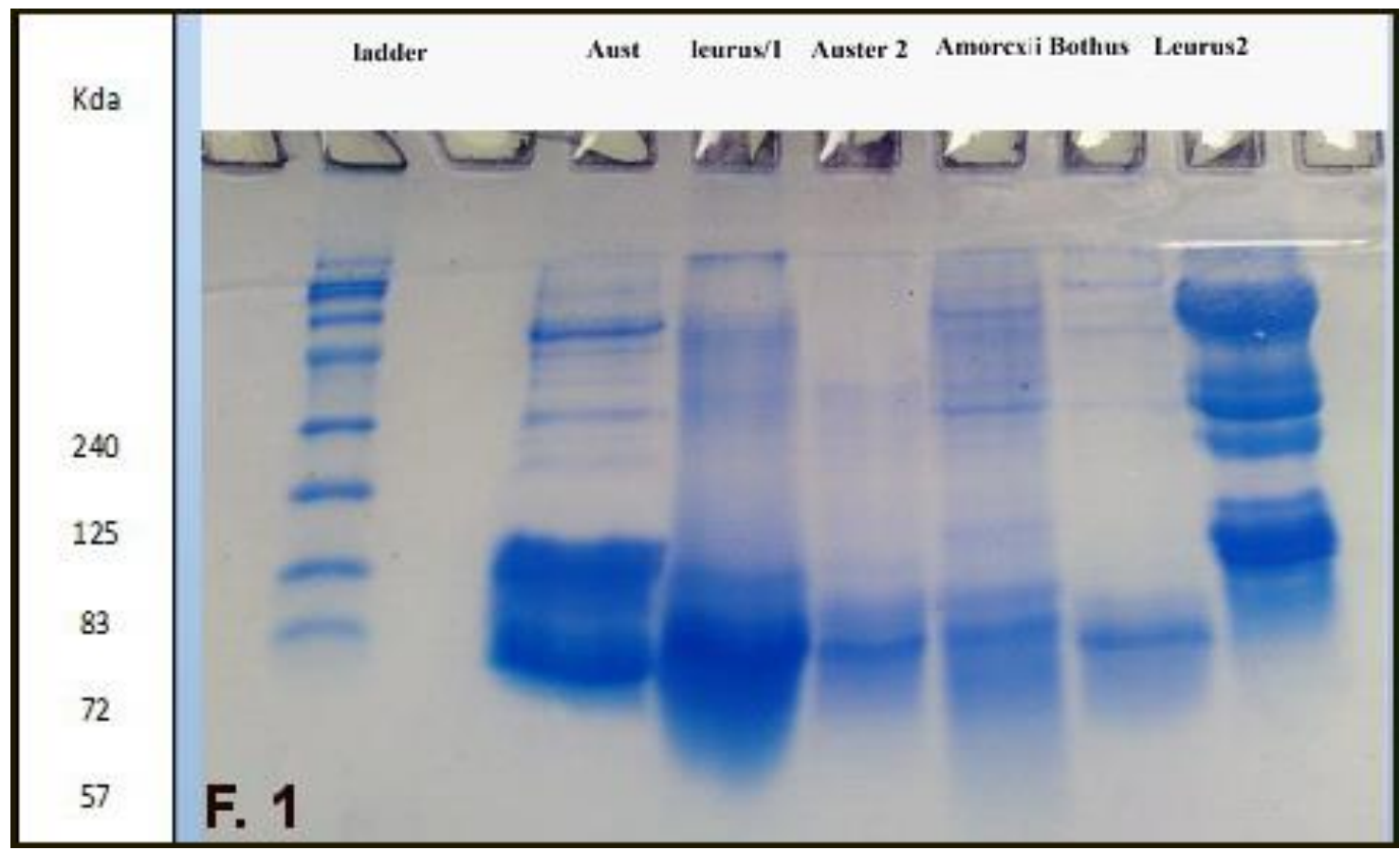



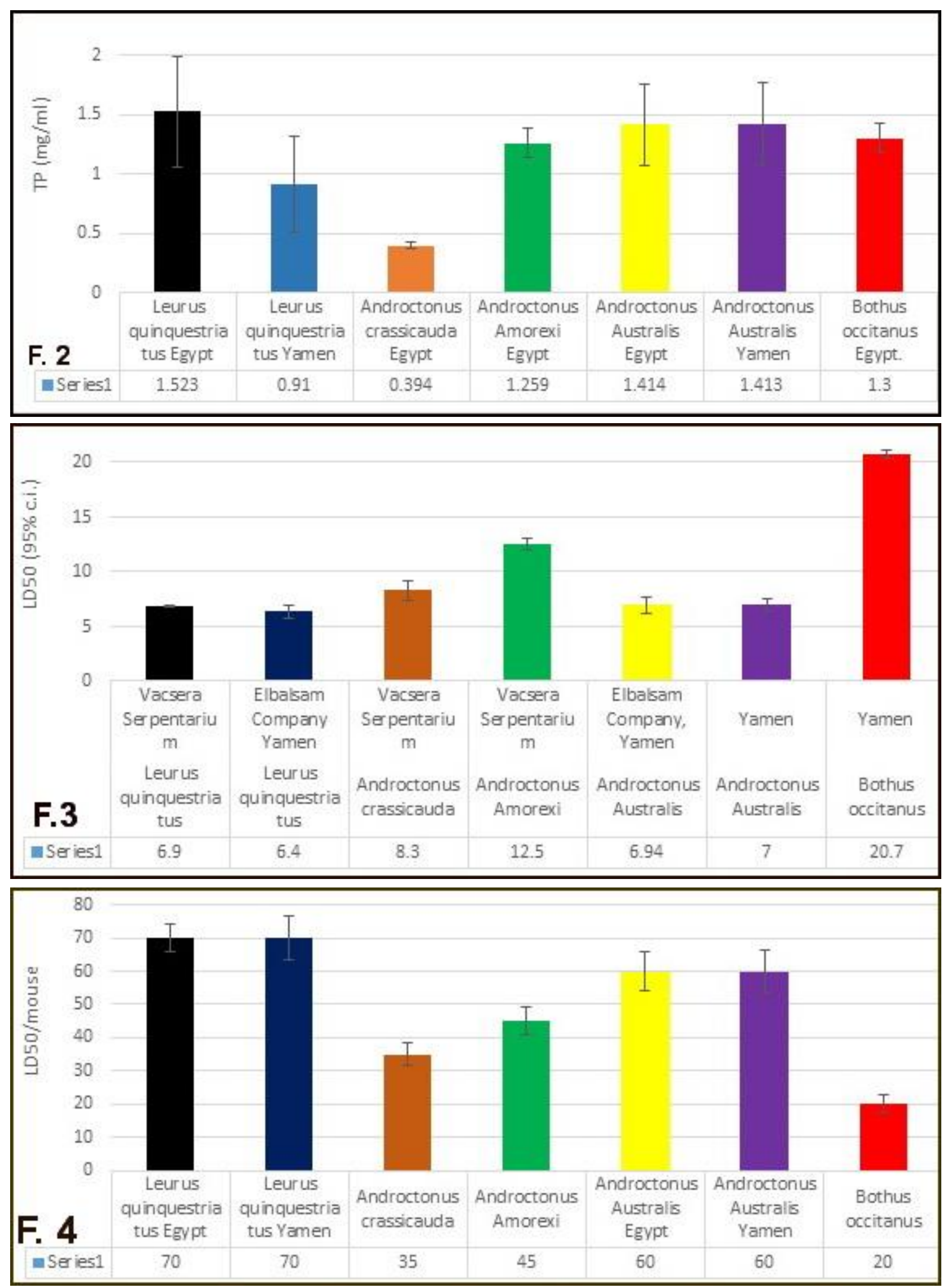